\author{
Marian GORYNIA \\ Barbara JANKOWSKA \\ Elżbieta MAŚLAK
}

\title{
Branża jako przedmiot badań w ekonomii
}

\section{Wstęp}

W ramach szeroko rozumianych nauk ekonomicznych obserwuje się silne i postępujące zróżnicowanie obiektów dociekań naukowych badaczy. Różne nurty, teorie, koncepcje, szkoly i paradygmaty ogniskują uwagę wokół odmiennych pól badawczych. Tradycyjnie przedstawiciele ekonomii specjalizowali się w badaniu zagadnień mikroekonomicznych i makroekonomicznych. W dwudziestym wieku pojawiły się nowe - w stosunku do tradycyjnego podziału obszary analizy, wyznaczone przez usytuowanie obiektów, których dotyczą, w całościowo ujmowanym systemie gospodarczym. Wyróźniono trzy dodatkowe poziomy analizy: mikromikro, mezo i globalny ${ }^{1}$.

W niniejszym artykule zajmujemy się poziomem mezo, a w szczególności jego przypadkiem, jakim jest branża. Rozwój zainteresowań funkcjonowaniem branż wynika z faktu, że tzw. otoczenie branżowe jest podstawową determinantą zachowań przedsiębiorstw. Analizy sektorowe stanowią przesłankę budowy strategii firm, są jednym z punktów wyjścia przygotowania koncepcji prywatyzacji sektorów, a także są uwzglẹdniane przy konstruowaniu koncepcji polityki przemystowej.

Autorzy artykułu wyrażają przekonanie, że mezoekonomia, a w szczególności jej fragment nazywany ekonomią branży, jest względnie samodzielnym obszarem badawczym. Za tak postawioną tezą przemawiają następujące argumenty:

1. branża, w sensie ontologicznym, jest dającym się wyodrębnić podsystemem gospodarki narodowej,

2. branżę, jako podsystem gospodarczy, cechuje wystẹpowanie specyficznych problemów badawczych,

3. branża z metodologicznego punktu widzenia, może być poznawana z zastosowaniem względnie autonomicznego zestawu metod badania naukowego. Aby wykazać słuszność powyźszej tezy w artykule podjęto kolejno następujące zagadnienia:

\footnotetext{
M. Gorynia jest pracownikiem naukowym Akademii Ekonomicznej w Poznaniu.

" B. Jankowska i E. Maślak są doktorantkami Akademii Ekonomicznej w Poznaniu.

1 Por. M. Gorynia, Poziony analizy w naukach ekononnicznych, „Ekonomista” 1993, nr 4.
} 
1. pojmowanie gospodarki jako systemu,

2. poziomy analizy występujące w ekonomii,

3. wyodrębnienie mezoekonomii w naukach ekonomicznych,

4. ontologiczny i epistemologiczny status branży,

5. podejścia badawcze stosowane w poznaniu branży,

6. problemy badawcze w ramach teorii struktury branży.

\section{Gospodarka jako system}

Systemowe ujmowanie problemów badawczych wiąże się z ogólną teorią systemów L. von Bertalanffy'ego ${ }^{2}$. Przypisuje się jej miano metateorii, gdyż nie dotyczy ona bezpośrednio konkretnych systemów, lecz posługuje się pojęciem abstrakcyjnym uogólnionego systemu. Jest więc teorią ogólną, która lączy w sobie dorobek dyscyplin bardziej szczegółowych ${ }^{3}$. Na gruncie ogólnej teorii systemów wyjaśnia się pojẹcie systemu oraz porządku hierarchicznego.

R.L. Ackoff definiuje system jako „zestaw składników, miẹdzy którymi zachodzą wzajemne stosunki"4. System tworzy więc zbiór co najmniej dwóch elementów i zdefiniowana na nim relacja, która bezpośrednio bądź pośrednio łączy ze sobą wszystkie elementy ${ }^{5}$. Natomiast porządek hierarchiczny systemu oznacza, że system jako całość składa siẹ z elementów niższego rzẹdu - podsystemów, które rekurencyjnie dzielą się na składniki jeszcze niższego rzẹdu, aż do osiągnięcia najniższego poziomu. Systemowi przypisuje się cechy jego czéści składowych i cechy typowe dla systemu w ujęciu całościowym, które wynikają ze związków między podsystemamí.

Myślenie w kategoriach systemów jest kompromisem pomiẹdzy postawą holistów i redukcjonistów, którzy na gruncie filozofii nauk społecznych wiodą spór, czy w rzeczywistoł́ci istnieją grupy, czy też może tylko jednostki ludzkie. Redukcjonizm (indywidualizm, elementaryzm) to opowiedzenie się za tezą, że ostateczne jednostki spoleczeństwa to jednostki ludzkie, natomiast holizm (kolektywizm) to ujmowanie społeczeństwa całościowo bez uwzględniania wpływu jednostek ludzkich - części składowych na prawidłowości rządzące społeczeństwem - całością ${ }^{7}$. Oba podejścia zostały zakwestionowane przez M. Bunge, który zaproponował podejście zwane systemizmem ${ }^{8}$.

Traktowanie gospodarki jako systemu wymaga od badacza wobec wyżej poczynionych uwag rezygnacji zarówno z postawy redukcjonistycznej, jak

Por. W. Gasparski, A. Lewicka, Problematyka badań systemowych, „Prakseologia" 1973, nr 2.

Por. W.N. Sadowski, Ogólna teoria systemów jako metateoria, „Prakseologia" 1973, nr 2.

Por. R.L. Ackoff, O system pojęc systemowych, „Prakseologia“ 1973, nr 2.

W ujęciu matematycznym graf tej relacji jest grafem spójnym.

Por. R.L. Ackoff, op. cit.

7 Por. „Wstęp do wydania polskiego“ - P. Sztompka, w: J.H. Turner, Struktura teorii socjologicznej, PWN, Warszawa 1985, s. 46.

8 Por. M. Bunge, A System Concept of Society. Beyond Individualizm and Holism, .Theory and Decision" 1979, vol, 10. 
i holistycznej. Gospodarka jako system to układ podsystemów gospodarczych - branż, które są tworzone przez przedsiębiorstwa ${ }^{9}$. Wyodrębnienie tychże podsystemów jest równoznaczne z próbą ich delimitacji w wymiarze pionowym ${ }^{10}$. W gospodarce wyróżnia się powiązania realne i informacyjno-decyzyjne, w których znajdują wyraz bezpośrednie bądź pośrednie więzi między branżami czy przedsiębiorstwami. Powiązania realne odnoszą się do przeplywu towarów i usług między podmiotami, natomiast informacyjno-decyzyjne mają koordynować i regulować procesy realne. Poszczególne branże, podobnie jak przedsiẹbiorstwa, mogą być w stosunku do siebie konkurentami (w bardzo szerokim tego slowa znaczeniu - o klienta, o lepsze warunki dostawy, o wpływy polityczne itp.), oferentami dóbr substytucyjnych, dostawcami, klientami czy kooperantami.

R.L. Ackoff podkreśla, że „....niektóre właściwości systemów moźna traktować tylko z całościowego punktu widzenia"11. Gospodarka posiada cechy, które są charakterystyczne tylko dla niej jako systemu w ujęciu całościowym i wynikają z zachowań oraz powiązań przedsiębiorstw, sektorów, branż - do cech takich należą np. koniunktura gospodarcza, stopień otwarcia gospodarki.

Hierarchiczna budowa gospodarki pozwala na wyróżnienie kilku poziomów analizy w ekonomii, które zostaną przedstawione w następnej części artykułu.

\section{Poziomy analizy w ekonomii}

Poziomy hierarchiczne realnych systemów gospodarczych znajdują swe odzwierciedlenie w poziomach analizy w ekonomii. Podstawowy podział współczesnej ekonomii to podzial na mikroekonomię i makroekonomię. Do lat trzydziestych XX wieku w naukach ekonomicznych w pełni dominowała mikroekonomia ${ }^{12}$. Początki makroekonomii to w zasadzie dopiero rok 1933 i osoba norweskiego ekonomisty - R. Frischa ${ }^{13}$. Pojawienie się makroekonomii zostało wywołane przez potrzebę wyjaśniania coraz bardziej skomplikowanych procesów rozwojowych, a wśród nich przyczyn sprawczych wielkich kryzysów, które występowały w gospodarce XIX wieku i międzywojennej ${ }^{14}$. Szczególne znaczenie dla rozwoju makroekonomii miała „Ogólna teoria zatrudnienia,

9 Przedsiębiorstwa to również systemy. Por. W.J. Otta, .Strategia przedsiębiorstwa", w: Przedsiębiorstwo na rynku międzynarodowym, red. T. Golębiowski, PWN, Warszawa 1994, s. 12.

10 Obok wymiaru pionowego istnieje również wymiar poziomy delimitacji, który dotyczy wyboru kryterium, wedlug którego dokonywane jest grupowanie podsystemów stanowiących skladniki określonego poziomu w hierarchii. Por. M. Gorynia, Delimitacja systemów gospodarczych w naukach ekonomicznych, .Ruch Prawniczy, Ekonomiczny i Socjologiczny", 1993, nr 2.

11 Por. R.L. Ackoff, op, cit.

12 Prekursorzy zagadnień makroekonomicznych to m.in. F. Quesnay (Tablica ekonomiczna), A. Smith, D. Ricardo (gospodarka Anglii, źródła bogactwa narodów). Por. M. Blaug. Teoria Ekonomii. Ujecie retrospektywne, PWN, Warszawa 1994.

13 Por. „Propagation Problems and Impulse Problems in Dynamic Economics”, w: „Economic Essays in Honour of Gustaw Cassel". George Allen and Unwin, London 1933, 5. 171-205.

14 Por. Cz. Bywalec, Mezoekonomia, „Zycie Gospodarcze*, 1993, nr 23. 
procentu i pieniądza" J.M. Keynesa, która zapoczątkowała okres dominacji makroekonomii w naukach ekonomicznych ${ }^{15}$.

Makroekonomia dostarcza wiedzy o funkcjonowaniu dużych gospodarek narodowych. Przedmiotem badań są m.in. następujące zagadnienia: globalna produkcja dóbr i usług, tempo wzrostu produkcji, inflacja, bezrobocie, ożywienie, recesja, bilans platniczy i kurs walutowy ${ }^{16}$. Mikroekonomia natomiast w centrum zainteresowań stawia gospodarstwa domowe i przedsiębiorstwa. Bada się kształtowanie popytu, podaży, cen, kosztów, wartości uźytkowej (użyteczności) w odniesieniu do przedsiębiorstw - producentów i gospodarstw domowych - nabywców ${ }^{17}$. W ramach makroekonomii analizuje się więc procesy zachodzące w dużych, złożonych systemach gospodarczych, natomiast mikroekonomia koncentruje siẹ na analizie zachowań ich podsystemów.

W drugiej polowie XX wieku pojawiły siẹ trzy następne poziomy analizy mikromikro, mezo i globalny ${ }^{18}$. Na istnienie poziomu mikromikro zwrócił uwagę H. Leibenstein ${ }^{19}$. W konwencjonalnej mikroteorii przyjmuje się, że gospodarstwo domowe i przedsiębiorstwo to podstawowi decydenci i uczestnicy życia gospodarczego. H. Leibenstein jest zdania, że założenie takie będzie prawdziwe, gdy gospodarstwo domowe i przedsiębiorstwo będą podmiotami jednoosobowymi. W rzeczywistości to ludzie funkcjonujący w ramach systemów, jakimi są przedsiębiorstwa i gospodarstwa domowe podejmują decyzje. Przedsiębiorstwa i gospodarstwa domowe to struktury molekularne i chcąc zbadać ich zachowanie się trzeba „badać organizację i struktury ich atomistycznych części składowych"20 Wobec tego wyróżnia on dodatkowy, w stosunku do konwencjonalnej mikroekonomii, poziom badań - poziom mikromikro i nazywa go mikroekonomią atomistyczną. Mikroekonomia konwencjonalna to dla H. Leibensteina mikroekonomia molekularna, która powinna być traktowana jako teoria zachowań pryncypałów (mocodawców). Natomiast mikroekonomia atomistyczna ma za zadanie identyfikację konsekwencji rozróźniania między pryncypałami a agentami. Można stwierdzić, że w pewnym stopniu tzw. teoria agencji zwraca uwagę na owe rozbieżności21. Prowadzenie analiz na poziomie mikromikro ściśle wiąże się z badaniem zachowań ludzi w organizacjach, co jest równieź centrum zainteresowań przedstawicieli teorii organizacji, np. M. Cyerta i J.G. Marcha22.

15 Ibid.

16 Por. R. Dornbusch, S. Fischer, Macroeconomics, McGraw-Hill, New York 1981.

17 Por. L.R. Miller, Intermediate Microeconomics. Theory, Isstes, Applications, McGraw-Hill. New York 1982.

18 Por. M. Gorynia, Teoria i polityka regulacji mezosystemów gospodarczych a transfornacja postsocjalistycznej gospodarki polskiej, AE Poznań 1995, s. 18.

19 Por. H. Leibenstein, EEkonomia atomistyczna versus ekonomia molekularna*, w: Ponad ekonomiq. PWN, Warszawa 1985, s. 287.

20 Ibid., s. 288

21 Por. M. Gorynia, Zachowania przedsiębiorstw w okresie transfonnacji. Mikroekonomia przejścia, AE Poznań 1998, s, 36-44.

22 Por. R.M. Cyert, J.G. March, A Behavioral Theory of the Firm, Prentice Hall, Englewood Cliffs, New York 1963. 
Kolejnym nowym poziomem analizy w ekonomii jest poziom mezo, który jest poziomem pośrednim między mikro i makro. Można wiẹc mówić o mezoekonomii lub inaczej ekonomii środka, gdyż mezo znaczy środkowy, pośredni. Analizy na poziomie mezoekonomicznym dotyczą podmiotów, które stanowią pośrednie ogniwo między poziomem makroekonomicznym i mikroekonomicznym, np. zrzeszenia, związki pracobiorców czy pracodawców, itd.23. Poziom mezo to główny przedmiot zainteresowań subdyscypliny zwanej teorią struktury branży, której twórcą jest J.S. Bain ${ }^{24}$. Mezoekonomia wykazuje silniejsze związki z mikroekonomią niż z makroekonomią.

Obecnie pojawia się coraz więcej wielkich korporacji międzynarodowych, których skala operacji czesto wykracza poza rozmiary działalności gospodarczej poszczególnych, mniejszych gospodarek narodowych. Tradycyjny podział na makroekonomię i mikroekonomię traci więc na znaczeniu i ostrości.

Ponad poziomem makroekonomicznym wyróżnia się dodatkowo poziom globalny. $\mathrm{Na}$ tym poziomie bada się zakres procesów globalizacji, przyjmując założenie, że gospodarka światowa to układ naczyń połączonych i w związku z tym obserwuje się wielostronne oddziaływania w planie przestrzennym oraz między różnorodnymi czynnikami - wielkością produkcji, zasobami, ludnością, środowiskiem naturalnym, techniką, organizacją i polityką ${ }^{25}$. Gospodarka światowa jest systemem umieszczonym na najwyższym szczeblu w hierarchii systemów gospodarczych, a gospodarki narodowe to jej podsystemy. Wyodrẹbnienie poziomu globalnego daje podstawy do mówienia o ekonomii „wyższego rzędu”, czyli zgodnie z dotychczasowo przyjętą nomenklaturą o megaekonomii26. W przeciwieństwie do mezoekonomii wykazuje ona silniejsze związki z makroekonomią niż z mikroekonomią.

Ewolucja w dziedzinie poziomów analizy w naukach ekonomicznych szła w dwóch kierunkach. Z jednej strony wyodrębniano poziomy nowe, wzglẹdnie autonomiczne, które nawiązywały do poziomów „tradycyjnych”. Z drugiej próbowano zintegrować osiągnięcia badawcze makroekonomii i mikroekonomii. Szczególne miejsce zajmuje tutaj tzw. synteza neoklasyczna powstała w latach sześćdziesiątych. Polegała ona na jednoczesnym wykorzystaniu makroekonomicznych tez Keynesa i systemu równowagi ogólnej Walrasa27.

Wśród nowych poziomów analizy w ekonomii ważne miejsce, zdaniem autorów artykułu zajmuje poziom mezo, dlatego w kolejnej czẹści opracowania zostanie bliżej zaprezentowana problematyka mezoekonomii.

23 Por, $\mathrm{C} z$. Bywalec, „Mezoekonomia i megaekonomia - nowe wymiary ekonomii*, w: Rola mezoekonomit w rynkowym systemie zarządzania, red. K. Górka, AE Kraków 1996, s. 20-21.

24 Por. J.S. Bain, Industrial Organization, John Wiley and Sons, New York 1959.

25 Por. S. Sztaba, .W oczekiwaniu na teoriẹ. Kierunki i problemy rozwoju problematyki globalnej", w: Przemiany we uspólczesnej ekonomii burzuazyjnej, red. J. Górski, PWE, Warszawa 1987.

26 Por: Cz. Bywalec, „Mezoekonomia i megaekonomia - nowe wymiary ekonomii”, op. cit., s. $22-23$.

27 Por. M. Belka, Wspólczesny keynesism. Enolucja i glówne kienunki, „Ekonomista” 1990, nr 4.5. 


\section{Mezoekonomia}

Powstanie poziomu mezo wiąże się z gwałtownym w ostatnich latach rozwojem podmiotów gospodarczych stanowiących ogniwo pośrednie pomiẹdzy mikro i makro. Należą do nich branże, kartele, zrzeszenia, związki pracodawców i pracobiorców, organizujące się grupy interesów, organizacje zajmujące się rozwojem gospodarek regionalnych czy też samorządy lokalne itp. ${ }^{28}$. Jako że funkcjonowanie tych struktur gospodarczych nie daje się w pełni opisać za pomocą teorii makro- czy mikroekonomicznych, wielu ekonomistów, glównie francuskich (F. Perroux, Y. Morvan, J.C. Perrin) i niemieckich (H.R. Peters) zaczęlo w ostatnich czasach postulować nadanie mezoekonomii rangi dyscypliny (a raczej subdyscypliny) naukowej. Przedmiotem jej badań jest ekonomika sektorów, działów i branż gospodarki narodowej, branż globalnych, regionów i grup spolecznych. Wśród kwestii interesujących mezoekonomistów znajduja się m.in. zagadnienia dynamiki mezosystemów, zmian w strukturze, zachowania członków mezosystemu. W. Janasz ${ }^{29}$ wskazuje również na praktyczny charakter mezoekonomii, której domeną powinna być rzeczywistość gospodarcza, przy rezygnacji z dużego stopnia uogólnienia i abstrakcji. Równocześnie proponuje się wydzielenie w ramach polityki społecznej tzw. mezopolityki, która zajmowałaby się polityką strukturalną. Szczególną rolę mezoekonomii, zwłaszcza polityki mezoekonomicznej upatruje się w procesie transformacji systemowej w Polsce ${ }^{30}$. Mezoekonomia ma się zajmować badaniami prawidłowości rozwoju i przemian strukturalnych, które dawałyby następnie odpowiedzi co do właściwej polityki przemysłowej państwa. Na potrzeby badań mezoekonomii opracowano główne założenia mezoanalizy. Jako jeden z istotnych postulatów M. Gorynia ${ }^{31}$ wymienia konieczność przyjęcia dla celów analizy podejścia dynamicznego, zakładającego obecność w branży procesów adaptacji do otoczenia. Jeśli chodzi o kierunki badań w mezoekonomii, to glównym zadaniem tej subdyscypliny jest badanie wszelkich systemów gospodarczych ulokowanych na poziomie pośrednim pomiędzy gospodarką kraju a poziomem pojedynczych przedsiębiorstw i instytucji. Jednym z istotnych kierunków zainteresowań są analizy odnoszące siẹ do branży. W ramach mezoekonomii wyróżnia siẹ kilka głównych nurtów związanych z problematyką branżową̧3:

- teoria organizacji branży (industrial organization), która zajmuje się cechami strukturalnymi rynków branżowych oraz dymaniką przemian na tych rynkach. Bada siẹ tutaj również modele duopolu i oligopolu służące analizie procesów konkurencji monopolistycznej;

28 C. Bywalec, Mezoekonomia, op, cit.

29 Podstawy ekonomiki przemyshu, red. W. Janasz, PWN, Warszawa 1997.

30 J. Gajda, Nowa rola mezoekonomii. „Zycie Gospodarcze“ 1994, nr 1.

31 M. Gorynia, Mezoekonomia - modele samoregulacji branży, „Ekonomista” 1995, nr 5-6, 5, 19.

32 Zob. M. Gorynia, W.J. Otta, Regulacja sfery turystyki zagranicznej. Przyczvnek do teorit regulacji systemóny gospodarczvelh, Instytut Turystyki, TNOiK, Poznañ 1991. 
- nurt strategicznego zachowania się (strategic behavior), który bada odpowiedzi branży na bodźce z zewnątrz, np. nowe wejścia;

- nurt normatywny, formulujący dyrektywy praktyczne pod adresem branżowej polityki gospodarczej (industrial policy);

- koncepcje branż globalnych (global industries) powstających w wyniku zacierania się znaczenia granic administracyjnych państw.

Korzenie ekonomii branży sięgają czasów A. Smitha, który rozwinął pojęcie ceny rynkowej produktu, tworząc tym samym podwaliny teorii firmy ${ }^{33}$. Prace jego nastẹpców poszly w dwóch kierunkach: badań empirycznych oraz rozważań teoretycznych. W latach trzydziestych E.H. Chamberlin ${ }^{34}$ dokonał klasyfikacji struktur rynku wedlug kryteriów liczby sprzedawców i stopnia zróżnicowania produktu oraz dokonał analizy relacji pomiędzy strukturą a efektywnością rynku. Analizy te stały się w latach pięćdziesiątych podstawą dla współczesnej teorii struktury branży. Obecnie w ramach teorii branży można wyróżnić kilka głównych podejść badawczych, które zostaną w dalszej czẹści pokrótce scharakteryzowane.

\section{Ontologiczny i epistemologiczny status branży}

Dążenie do poznania branży to próba odpowiedzi na pytanie czym jest branża, jaki jest charakter i struktura rzeczywistości, którą nazywa się branżą. Wyjaśnienie istoty branży wymaga wyznaczenia jej granic w wymiarze pionowym i poziomym ${ }^{35}$. W literaturze występuje kilka podejść do problemu delimitacji branży. Na gruncie teorii struktury branży zakłada się, że w branżę grupowane są przedsiębiorstwa wytwarzające te same produkty ${ }^{36}$. A. Marshall postulowal, aby za kryterium delimitacji przyjąć homogeniczność technologii produkcji. Według A. Marshalla ułatwiłoby to przedsiębiorcom zakreślenie obszaru konkurowania. Do tej samej branży należałyby wtedy przedsiębiorstwa wytwarzające produkty o takich samych charakterystykach technicznych ${ }^{37}$. W centrum zainteresowania znalazła się więc strona podaźowa gospodarki. Koncepcja A. Marshalla pomijała jednak fakt, że dobra mogą być w stosunku do siebie substytutami i jednakowe produkty mogą być wytwarzane przy użyciu różnych technologii. Koncepcje E.H. Chamberlina, J. Robinson, A. von Stackelberga, L. Abbotta, J.S. Baina, M.E. Portera odbiegaly od poglądów A. Marshalla, gdyż połoźyli oni akcent na stronẹ popytową gospodarki. Uwzglẹdnili oni możliwości substytucji między dobrami i zwrócili uwagę na potrzeby odbiorców. E.H. Chamberlin budując model konkurencji monopolistycznej po-

33 Por. D.A. Hay, D.J. Morris, Indtustrial Economics. Theory and Evidence, Oxford University Press, Oxford 1979.

34 E.M. Chamberlin, The Theory of Monopolistic Competition, Oxford University Press, London 1949 (1933).

35 Por. M. Gorynia, Delimitacja svstemów gospodarczych, op. cit.

36 Ibid.

37 Por. A. Marshall, Principles of Economics, Macmillan, London 1972. 
służył się pojęciem grupy konkurujących ze sobą firm (competing group of firms) - producentów bliskich substytutów, którzy tworzyli określoną branżę ${ }^{38}$. J. Robinson wykorzystała z kolei pojęcie luki substytucyjnej. Całość towarów na rynku tworzy łańcuch substytucji, który w niektórych miejscach jest poprzerywany - tam wystẹpują luki substytucyjne ${ }^{39}$. Wybrane przez nią kryterium delimitacji branży to homogeniczność potrzeb ${ }^{40}$. Podobnie A. von Stackelberg do jednej branży zaliczył przedsiębiorstwa, których produkty zaspokajają takie same potrzeby ${ }^{41}$. Dla L. Abbotta branża to rynek branżowy, który jest wydzielany na podstawie zdolności do zaspokajania pewnej elementarnej potrzeby ${ }^{42}$. J.S. Bain stwierdzil, że granice rynku branżowego wyznacza wysoki współczynnik elastyczności krzyżowej ${ }^{43}$. M.E. Porter twierdzi, że określoną branżę tworzą producenci substytutów ${ }^{44}$. Rozbieżność stanowisk zmusza prowadzącego badania do przyjęcia takiej definicji branży, która bẹdzie najbardziej adekwatna z punktu widzenia celów badawczych.

Branża to jeden z systemów gospodarczych, który składa się z mniejszych systemów - przedsiębiorstw ${ }^{45}$. Systemowe właściwości branży wyrażają także powiązania, jakie wystẹpują wewnątrz branży między przedsiębiorstwami oraz między daną branżą a jej elementami. Mają one charakter więzi realnych między przedsiębiorstwami w branży ma miejsce przepływ towarów, usług i więzi regulacyjnych - wzajemny wpływ mikropodmiotów na swoje posunięcia, np. poprzez stosowane strategie.

Interakcje branża - przedsiębiorstwa również w głównej mierze ujawniają się w sferze regulacyjnej. Jest to moźliwe dzięki funkcjonowaniu samorządów branżowych oraz określonych reguł gry na danym rynku branżowym. Reguły te mogą wynikać z obowiązujących rozwiązań prawnych bądź zwyczajów ${ }^{46}$. Źródłem wpływu branży na tworzące ją przedsiębiorstwa są także jej specy. ficzne właściwości.

Mezosystem gospodarczy jakim branża jest posiada dwie kategorie cech. Pierwsza kategoria to cechy, które można przypisać przedsiębiorstwom, a więc zredukować do cech przedsiębiorstw, np. efektywność i rentowność, dysponowanie określoną technologią. Druga kategoria to cechy nieredukowalne do cech mikropodmiotów w branży. Do tych drugich należą: struktura - organizacja branży od konkurencji doskonałej po monopol, stopień koncentracji, cykl życia, istnienie grup strategicznych, bariery wejścia do i wyjścia z branży, ist-

38 Por. D.A. Hay, D.J. Morris, op. cit., s. 10.

39 Por. J. Robinson. The Economics of Imperfect Competition, London 1969, s. 17.

40 Ibidem.

41 Por. H. von Stackelberg, Marktform und Gleichgewicht, Wien, Berlin 1934, s. 29.

42 Por. L. Abbott, Qualität und Wettbewerb, München 1958, s.96.

43 Por, J.S. Bain, op. cit, S. 6-7.

44 Por. M.E. Porter, Choix Strategiques et Concurrence, „Economica”, Paris 1982, za: M. Gory. nia, Teoria regulacji...., op. cit., s. 26.

45 Por. W.J. Otta, Teoria przedsiębiorstwa a przejście do gospodarki rynkonvej. „Ekonomista” 1996. nr 1.

40 Por, M. Gorynia, Zachowania przedsiębiorstw..., op. cit., s. 61. 
nienie stanu równowagi bądź nierównowagi na danym rynku branżowym. Struktura i koncentracja branży determinują natężenie procesów konkurencyjnych oraz kooperacyjnych w branży. Liczba i siła podmiotów w branży wpływają na decyzje cenowe pojedynczych przedsiębiorstw ${ }^{47}$. Nie wszystkie podsystemy branży działają na zasadach komercyjnych, co różni niekiedy branżę od przedsiębiorstwa ${ }^{48}$. Systemowe właściwości branży przemawiają za uznaniem jej za dający się wyodrębnić podsystem gospodarki narodowej, a więc za samodzielny byt w sensie ontologicznym. Dodatkowo warto zauważyć, że coraz częściej mówi się o potrzebie prowadzenia selektywnej polityki przemyslowej ${ }^{49}$. Adresatem jej wytycznych jest branża, a nie konkretne przedsiębiorstwo ${ }^{50}$. Zachowanie branży jest współdeterminowane przez zachowania tworzących ją mikropodmiotów. Podobną zależność można zaobserwować między gospodarkạ a branżami.

Dążąc do poznania branży trzeba pamiętać o jej systemowych wlaściwościach ${ }^{51}$. Warto posłużyć się analizą wielopoziomową, która daje szanse uzyskania moźliwie dokładnego wizerunku branży ${ }^{52}$. Krótka prezentacja podejść badawczych stosowanych w poznaniu branży zostanie przedstawiona w kolejnej częśsi artykułu.

\section{Podejścia badawcze w poznaniu branży}

Teoria branży nierozłącznie związana jest z teorią firmy, zajmującej się badaniem zachowań pojedynczych przedsiębiorstw na rynku. Mająca o wiele starsze korzenie teoria firmy sięga czasów A. Smitha ${ }^{53}$, który analizowal rolę przedsiębiorstwa w procesie postępu i rozwoju gospodarczego. Kolejne rozważania szły w kierunku badania zagregowanych zachowań przedsiębiorstw na rynkach, i w dalszej konsekwencji, do analiz branż. Chociaż teoria firmy i teoria branży mają wiele wspólnych punktów zainteresowania, a badania w obu dziedzinach często zachodza na siebie, należy jednak wyraźnie podkreślić odrębność obu tych paradygmatów. Wynikają one z następujących własności:

1. Różnice w przedmiocie badań. Teoria branży zajmuje się badaniem procesów zachodzących w sektorach lub branżach, natomiast teoria firmy bada zachowanie firmy na rynkach oraz zjawiska na poziomie przedsiębiorstw. Branża posiada cechy, które nie są redukowalne do poziomu przedsiębior-

47 Por. D.A. Hay, D.J. Morris, op. cit., chapter 4, 5.

48 W granicach branży mogạ działać np. instytuty i towarzystwa wspierające wspólpracẹ miẹdzy przedsiębiorstwami.

49 W tym miejscu abstrahujemy od oceny tych poglądów.

50 Por. D. Hübner, Międzynarodowa konkurencyjność gospodarki a strategia rozwoju, „Ekonomista" 1994, nr 3.

51 Por, M. Bunge, A System Concept..., op. cit.

52 Por. W.J. Otta, Zachowanie się przedsiębiorstw handlu zagranicznego. Przyczynek do teorii przedsiębiorstwa w gospodarce socjalistycznej. AE Poznań 1986, 5. 43.

53 A. Smith, An Inquiry into the Nature and Causes of the Wealth of Nations, Ward, Lock and Co., London 1812 (1776). 
stwa (np. stopień koncentracji, bariery wejścia, poziom wejść do branży, „umieralność”) i odwrotnie - w przypadku firm analizuje się zjawiska, których nie moźna rozciągnąć na całą branżę (np. konflikty wewnątrz organizacji).

2. Teoria firmy zajmuje się zachowaniem przedsiębiorstw na rynku, nie zaś w branży ${ }^{54}$. Rynek, jako miejsce wymiany pomiędzy kupującymi a sprzedającymi, jest czẹściowo odmienną kategorią niż branża.

3. Pojedyncze przedsiębiorstwo może działać w wielu branżach. Wtedy w analizie branżowej istotne są tylko te zachowania firmy, które odnoszą się do danej branży. Nie jest więc moźliwa prosta agregacja.

4. Teoria branży zawiera elementy normatywne, jednym z jej celów jest bowiem formułowanie dyrektyw pod adresem polityki państwa. Teoria firmy natomiast w większym stopniu koncentruje się na aspektach poznawczych. Poniżej zostaną omówione podstawowe nurty badawcze z zakresu teorii branży. Należą do nich:

1. teoria neoklasyczna,

2. nurt szkoły austriackiej,

3. teorie behawioralne,

4. teorie menedżerskie,

5. nowa ekonomia instytucjonalna,

6. ewolucyjna teoria branży.

\section{Teoria neoklasyczna}

Początki neoklasycznej teorii firmy przypadają na drugą połowę XIX w. W swych podstawach paradygmat neoklasyczny nawiązuje do teorii klasycznych wskazujących na podażowe źródła rozwoju gospodarczego oraz przekonań o samodostosowującej się naturze wolnego rynku. Głównym rdzeniem teorii jest model równowagi ogólnej odnoszący się do sytuacji rynku doskonałego ${ }^{55}$. W przypadku rynku doskonałej konkurencji do głównych założeń należąi ${ }^{56}$

- Duża liczba sprzedających i kupujących na rynku.

- Wysoki stopień homogeniczności produktów.

- Brak barier wejścia i wyjścia z branży.

- Jeden cel w postaci maksymalizacji zysku.

- Brak aktywności państwa.

- Doskonała mobilność czynników produkcji.

- Pełna wiedza na temat rynku.

54 Por. P.J. Devine, R.M. Jones, W.J. Tyson, An Introduction to Industrial Economics, George Allen \& Unwin, London 1974, s. 32.

55 Model opracowany zostal przez L. Walrasa, a nastẹpnie rozwijany przez V. Pareto, J.R. Hicksa, P.A. Samuelsona oraz sformalizowany przez K.J. Arrowa i G. Debreu (Existence of an Equilibrium for Competitive Economy, „Econometrica”, vol. 22(3), 1954).

S6 Zob. A. Koutsoyiannis, Modem Microeconomics, Macmillan, London 1975, s. 154-155. 
Obok tych założeń warto zwrócić uwagẹ na założenia behawioralne dotyczące racjonalności i maksymalizacji zysków. Mając daną tak określoną branżę, analizuje się zachodzące w niej procesy. W najprostszym rozumieniu równowaga ogólna jest zagregowaną sumą równowag na rynkach cząstkowych powstających w wyniku konfrontacji popytu $\mathrm{z}$ podażą ${ }^{57}$. W kategoriach rachunku marginalnego nastẹpuje zrównanie przychodów i kosztów krańcowych. Stan równowagi cechuje się optymalną alokacją zasobów oraz brakiem zysków ${ }^{58}$. Każda zmiana wywołana przez czynniki zewnętrzne powoduje natychmiastową reakcję dostosowawczą, w wyniku której branża osiąga nowy punkt równowagi. Do głównych cech paradygmatu neoklasycznego należą:

1. Indywidualizm metodologiczny polegający na traktowaniu zjawisk w branży jako prostej sumy zachowań wszystkich przedsiębiorstw.

2. Przyjęcie behawioralnych założeń racjonalności i maksymalizacji zysków.

3. Koncepcja przedsiębiorstwa jako czarnej skrzynki.

4. Statyczny charakter analiz.

5. Egzogeniczne określenie zasobów produkcyjnych oraz gustów i preferencji.

6. Przy danym określeniu układu akty wyboru ograniczają się do wyborów relatywnych w obrẹbie danych możliwości ${ }^{59}$.

7. Przyjęcie ceny jako jedynego miernika rynku.

Mimo licznych krytyk teorii neoklasycznej (dotyczących traktowania przedsiębiorstwa jako czarnej skrzynki oraz nierealności założeń), stanowi ona wciąż dominujący paradygmat badań, a pozostałe nurty noszą jedynie charakter w znacznej mierze komplementarny.

\section{Szkoła austriacka}

Glównym rdzeniem teorii wywodzących się ze szkoły austriackiej jest przekonanie o ciągłej zmienności układu gospodarczego ${ }^{60}$. Stąd też dużym zainteresowaniem cieszą się badania różnego typu procesów konkurencyjnych. Ponieważ brak stanów równowagi utrudnia znalezienie punktów odniesienia, analizy szkoły austriackiej tracą porównawczy charakter - jakość gospodarki badana jest w kategoriach korzyści wynikających z otwierania nowych rynków, wprowadzania nowych produktów itp. W obszarze polityki państwowej przedstawiciele szkoły austriackiej stoją na straży poglądu o nieefektywnym działaniu państwa, które nieustannie zaklóca optymalizacyjną rolę wolnej konkurencji. Do cech szkoły austriackiej należy przekonanie o samoregulującej roli rynku, brak zainteresowania badaniami efektów zewnętrznych oraz problemem redystrybucji dochodu. Niewątpliwą zaletą jest natomiast zerwanie ze statyczną koncepcją branży ${ }^{61}$.

57 Zob. W.D. Nordhaus, P.A. Samuelson, Ekonomia cz. II, PWN, Warszawa 1996, S. 675-679

58 M. Gorynia, Zachonania przedsiẹbiorstw.... op. cit, s. 17.

59 Zob. Ekonomia w prevszlości, red. K. Dopfer, PWN, Warszawa 1982, s. 17.

${ }^{60}$ Zob. M. Waterson, Economic Theory of the Industry, Cambridge University Press, Cambrid. ge 1984, s. 11 .

61 Więcej informacji na temat teorii szkoły austriackiej można znaleźć u W.D. Reekie, Industry, Prices and Markets, Philip Allan, Oxford 1979. 


\section{Teorie behawioralne}

Teorie behawioralne stanowią grupę poglądów, których cechą wspólną jest dążenie do urealnienia założeń neoklasycznych sprowadzające się do następujących postulatów ${ }^{62}$ :

1. Odejście od koncepcji przedsiębiorstwa jako czarnej skrzynki;

2. Uwzględnienie interesów wszystkich osób związanych z przedsiębiorstwem;

3. Odejście od założenia o maksymalizacji zysku jako jedynym motywie dzia-

łania przedsiębiorstwa na rzecz założenia o zachowaniu satysfakcjonującym;

4. Odrzucenie założeń o pelnej racjonalności na rzecz racjonalności ograniczonej wynikającej z braku pełnej informacji63;

5. Odejście od ceny jako głównego nośnika informacji o rynku;

Jedną z tych teorii jest koncepcja „nieefektywności X" H. Leibensteina, wskazująca na istnienie czynników powodujących, iż firma nie jest w stanie znaleźć się na właściwych krzywych kosztów i w efekcie nie może dokonywać optymalnej alokacji zasobów. W przypadku monopolu teoria ta wyjaśnia wzrost kosztów produkcji wskutek zmniejszenia presji ze strony rynku, pomimo uzyskanych przez monopolistę korzyści skali.

Inną teorią jest koncepcja zachowania satysfakcjonującego Cyerta i Marcha $^{64}$. Cele przedsiębiorstwa dotyczą różnych aspektów jego funkcjonowania i odnoszą się do sfery produkcji, zysku, udziału w rynku, wielkości sprzedaży i poziomu zapasów. Istnieje duża zależność pomiędzy poziomem aspiracji a przeszlymi osiągnięciami jednostek. Głównym celem teorii jest określenie kluczowych zmiennych biorących udział w procesie decyzyjnym.

Do nurtu behawioralnego należy również grupa poglądów broniących hipotezy, iż w branżach o wysokiej koncentracji, duże korporacje mają swobodẹ ustalania cen, które noszą charakter cen administrowanych ${ }^{65}$, niewrażliwych na zmiany w popycie i podaży.

Cechą wyróżniającą nurt behawioralny jest wizja przedsiębiorstwa składającego się z wielu jednostek o zróżnicowanych, przeciwstawnych celach, podejmujących decyzje w warunkach niepewności i cechujących się ograniczoną racjonalnością. Do wad tych teorii moźna zaliczyć zbytnie skupienie się na aspektach behawioralnych i wynikające z tego pominięcie całokształtu zjawisk gospodarczych w branźy. Chociaż teorie te w większym stopniu dotyczą zachowań pojedynczych przedsiębiorstw niż branż, to jednak przyjęcie behawioralnej wizji firmy niesie kilka istotnych konsekwencji dla badania branży. Należą do nich:

62 M. Gorynia, Zachowania przedsiębiorstw..., op. cit, 5. 30-31.

63 Koncepcję ograniczonej racjonalnosci wprowadzil H.A. Simon, por. H.A. Simon, Administrative Behavior, 2nd ed., Free Press, New York 1957 (1945).

64 Zob. R.M. Cyert. J.G. March, A Behavioral Theory of the Firm, op, cit.

65 Zob. G.C. Means, The Corporate Revolution in America, Crowell-Collier Press, New York 1962. 
1. Modelowanie procesów konkurencyjnych w oparciu o kryteria inne niż maksymalizacja zysku.

2. Uwzględnianie większej liczby zmiennych na poziomie explanansu, którym jest przedsiębiorstwo (w teorii neoklasycznej jedynymi parametrami rynku są ilości i ceny).

3. Wprowadzenie do analiz branży czynnika niepewności.

4. Możliwość wyjaśniania zakłóceń w samo-optymalizującym działaniu wolnego rynku (teoria cen administrowanych).

5. Zdolność wyjaśniania zachowań monopolistycznych.

\section{Teorie menedżerskie}

Osobną, lecz również niejednorodną, grupę poglądów stanowią menedżerskie teorie firmy ${ }^{66}$. Przedsiębiorstwo postrzegane jest jako koalicja różnych grup interesu o sprzecznych wzajemnie celach. Zasadniczą koncepcją leżącą u podłoża teorii menedżerskich jest fakt rozdziału własności i kontroli ${ }^{67}$ widoczny zwłaszcza w przypadku dużych koncernów o rozproszonym akcjonariacie. W firmie analizuje się trzy szczeble władzy: akcjonariat, zarząd oraz kierownictwo ${ }^{68}$. Faktycżna władza spoczywa w rẹkach zarządu i kierownictwa, którzy decydują o celach firmy, nie zawsze zgodnych z maksymalizacją zysku. Podobnie jak w przypadku teorii behawioralnych, również i teorie menedżerskie koncentrują się na badaniu zachowań na poziomie firmy, jednakże rezultaty tych badań niosą istotne implikacje dla analiz branźy, szczególnie wtedy, kiedy uzyskane z analizy firmy wnioski każą odrzucać czy też modyfikować założenia o maksymalizującym zachowaniu podmiotów branży. Glównymi założeniami teorii menedżerskich są $^{69}$ :

1. Odejście od maksymalizacji zysku jako jedynego celu przedsiębiorstwa;

2. Zerwanie z koncepcją przedsiębiorstwa jako czarnej skrzynki;

3. Traktowanie firmy jako koalicji różnych grup interesu;

4. Cele menedżerów polegają na maksymalizacji własnej uźyteczności, przy zachowaniu minimalnego wymaganego poziomu zysków. Cele te mogą dotyczyć:

- maksymalizacji przychodów ze sprzedaży,

- maksymalizacji stopy wzrostu przedsiębiorstwa,

- preferencji dla pewnych rodzajów wydatków.

W literaturze moźna wyróźnić trzy nurty rozważań, które nie zostały jeszcze rozstrzygająco zweryfikowane na gruncie empirycznym ${ }^{70}$ :

- zagadnienie rozdziału kontroli i własności,

o6 Przegląd tych teorii można znaležc w: J.R. Wildsmith, Managerial Theories of the Firm, Martin Robertson, London 1973

67 Jako pierwsi zwrócili uwagę na postępujący rozdział kontroli i wlasności A.A. Berle i G.C. Means, zob. The Modem Corporation and Private Property, Macmillan, New York 1936 (1932).

68 Zob. A. Koutsoyiannis, op. cit., s. 342

69 M. Gorynia, Zachowania przedsiębiorstw.... op. cit., s. 23.

70 P.J. Devine at al., op. cit., s. 166. 
- problem konfliktu pomiẹdzy różnymi grupami interesu,

- stopień dowolności w zarządzaniu przedsiębiorstwem i ustalaniu jego celów.

W modelu Baumola ${ }^{71}$ przyjmuje się, iż w obliczu słabości akcjonariatu, menedżerowie ustalają wlasne cele, które związane są z maksymalizacją przychodów ze sprzedaży. Wynika to z faktu, że poziom nagród i zarobków jest w większym stopniu skorelowany ze wzrostem obrotów handlowych niż zysku.

W teorii Marrisa prezentowany jest z kolei pogląd, iż cele menedżerów i właścicieli nie sa w istocie rzeczy bardzo rozbieżne. Obie strony czerpią duże korzyści z osiagnięcia celu, jakim jest maksymalizacja stopy wzrostu przedsiębiorstwa $^{72}$. Stopa wzrostu firmy zdeterminowana jest przez takie czynniki, jak ${ }^{73}$ : wielkość i możliwość wzrostu popytu i podaży, zasoby finansowe, cele kierownictwa i efektywność pracy menedżerów.

W teorii Williamsona przyjmuje się, iż menedżerowie posiadają pewną swobodẹ przy ustalaniu wiązki swoich celów, wsród których należy dążenie do poczucia bezpieczeństwa, władzy, prestiżu, awansu ${ }^{74}$. Większość tych celów ma charakter niematerialny, są więc one ujęte koncepcję „preferencji dla pewnych wydatków"75, która wyznacza satysfakcję osiągniętą z dokonywania pewnych typów wydatków. Takie zachowania przynoszą efekty w postaci nieopty. malnej alokacji zasobów.

Teoria Yarrowa ${ }^{76}$ prezentuje odmienne podejście do omówionych modeli. Analizuje on mianowicie nie cele, lecz ograniczenia, jakie są nakładane na działania menedżerów, wynikające z dążenia przez akcjonariuszy do uzyskania własnych korzyści oraz ryzyka utraty pracy wskutek bankructwa. Przyjęcie takiego podejścia prowadzi do odkrycia nowych motywów decyzji menedżerskich.

Fakt uwzględnienia rozdziału kontroli i własności w przedsiębiorstwie oraz dopuszczenie różnych motywów postępowania przedsiębiorców niesie pewne implikacje dla teorii branży. Do najważniejszych z nich należą: zerwanie z neoklasyczną koncepcją maksymalizacji zysku, nacisk na badanie procesów w branży odbiegających od modelu doskonałej konkurencji oraz wyjaśnianie działalności i roli wielkich korporacji w funkcjonowaniu branży. Przyjęcie założenia o istnieniu celów innych niż maksymalizacja zysku stwarza nową perspektywę do badania procesów konkurencyjnych w branży. Rywalizacja dokonuje się tu już nie w kategoriach zwiększania zysków, ale np. maksymalizowania wo-

71 W.J. Baumol, Business Behavior, Value and Growth, Macmillan, New York 1959.

72 Zob. R. Marris, A Model of the .Managerial Enterprise", „Quaterly Journal of Economics" 1963. vol. 77(2) oraz R. Marris, The Economic Theory of Managerial Capitalism, Macmillan, London 1967 (1966).

73 M. Gorynia, Zachonvania przedsiętiorstw..., op. cit., s. 25.

74 O.E. Williamson, Economic Organization. Firms, Markets and Policy Control, Wheatsheaf Books, Brighton 1986, s. 6.

75 O.E. Williamson, Managerial Discretion and Business Behavior, „American Economic Review", 1963, vol. 53(5), s. 1034

70 G.K. Yarrow, On the Predictions of Material Theories of the Fim,. Journal of Industrial Economics" 1976, vol. 24(4). 
lumenu sprzedaży, minimalizacji kosztów poprzez aktywne oddziaływanie na wielkości popytu i podaży. Dużo uwagi poświęca się roli promocji, inwestycji oraz znaczeniu instytucji finansowych dla rozwoju branż.

\section{Nowa ekonomia instytucjonalna}

Nowa ekonomia instytucjonalna stanowi szeroki nurt interdyscyplinarny, korzystający z osiągnięć nauk politycznych, prawa, zarządzania, teorii gier oraz historii gospodarczej. Wspólną cechą tych teorii jest badanie zjawisk w branży w aspekcie otoczenia instytucjonalnego. O.E. Williamson wyróżnia dwa podejścia $\mathrm{c}^{77}$ :

- nurt efektywnościowy - odstępstwa od klasycznej wymiany rynkowej służą celom oszczędnościowym;

- nurt monopolu - odstępstwa od klasycznej normy są związane z celem monopolistycznym.

W ramach nurtu efektywnościowego wyodrębnia siẹ kilka kierunków badań. Teoria kosztów transakcyjnych zajmuje się analizą procesów rynkowych w kategoriach kosztów transakcyjnych. Oszczędności kosztów transakcyjnych przy danej specyficzności zasobów realizuje się poprzez wpisanie kontraktu w ramy struktury organizacyjnej, która może przybierać różne formy: od organizacji rynkowej po scentralizowaną strukturę hierarchiczną. Teoria agencji bada z kolei koszty nadzoru nad wykonaniem umowy, w przypadku gdy zarządzający przedsiębiorstwem jest wynajętym agentem. Analizuje się możliwości i sposoby wpływu właściciela na agenta. Teoria praw własności bada funkcjonowanie rynku w zależności od rodzaju własności wobec dóbr na nim występujących.

W ramach gałęzi monopolowej bada się praktyki monopolowe w stosunku do nabywców oraz wobec rywali. Wśród tych pierwszych wyróżnia się koncepcję dźwigni monopolistycznej, pozwalającej monopoliście zwiększać swoją władzę oraz koncepcję dyskryminacji cenowej, która zakłada, że siła monopolu nie ulega zmianie, może się jednak ujawniać poprzez dyskryminację cenową. Praktyki stosowane wobec rywali można podzielić na dążenia do zwiẹkszenia barier wejścia oraz działania strategiczne mające na celu umocnienie władzy na rynku.

Do głównych cech nowej ekonomii instytucjonalnej można zaliczyć:

1. przyjęcie behawioralnych założeń ograniczonej racjonalności i oportunizmu,

2. rola otoczenia instytucjonalnego,

3. indywidualizm metodologiczny,

4. funkcjonalny charakter wyjaśniania zjawisk ${ }^{78}$,

5. działanie rutynowe jednostki. Nawyki i rutyny mają na celu zaoszczędzenie czasu na dokonywanie drobnych wyborów ${ }^{79}$,

77 Zob. O.E. Williamson, Ekonomiczne instytucje kapitalizmu, PWN, Warszawa 1998, s. 37.

78 Por. M. Rutherford, Institutions in Economics. The Old and the New Institutionalism, Cambridge University Press, Cambridge 1996, s. 43 i dalej.

79 Zob. R.R. Nelson, S.G. Winter, An Evolutionary Theory of Economic Change. The Belknap Press of Harvard University Press, Cambridge Mass. 1982. 
6. normatywny aspekt teorii. Wskazując na możliwości zakłóceń w funkcjonowaniu rynku (efekty zewnętrzne) nie wyklucza się roli państwa we wspieraniu rynku.

\section{Nurt ekonomii ewolucyjnej}

Ekonomia ewolucyjna powstała jako efekt zainteresowania ekonomistów procesami zachodzącymi w świecie przyrody. Samo pojęcie „ewolucja” od XVII wieku używane było do opisu różnorodnych zjawisk: począwszy od procesu wyłaniania się pewnego zorganizowanego porządku (H. Spencer, F.A. Hayek), poprzez historyczny dynamiczny rozwój gospodarki i społeczeństwa (K. Marks, J.A. Schumpeter), wyjaśnianie zjawisk społecznych przez uciekanie się do analogii ze świata przyrody (A. Smith, A. Marshall) aź po współczesne teorie analizy dynamicznych procesów w branży wywolywanych przez innowacje, wykorzystujace koncepcje zawarte w teorii doboru naturalnego C. Darwina (R.R. Nelson, S.G. Winter). Ten ostatni kierunek, określany mianem ekonomii ewolucyjnej w swych podstawach nawiązuje do teorii J.A. Schumpetera, traktującej innowacje jako główną siłę napędową procesów w branży. Do glównych cech paradygmatu ewolucyjnego należą 80 .

1. odrzucenie neoklasycznych założeń o racjonalności i maksymalizacji zysku firm na rzecz ograniczonej racjonalności i zachowania satysfakcjonującego,

2. funkcjonalny często charakter wyjaśniania,

3. przyjęcie założenia o rutynowym podejmowaniu prostych decyzji,

4. historyczny charakter analiz (koncepcje tzw. Ścieżki rozwojowej) ${ }^{81}$,

5. przesuniẹcie centrum zainteresowania z badań stanów równowagi na badania procesów zmian wywoływanych przez czynniki endogeniczne,

6. nacisk na rolę innowacji technicznych w procesach $z_{\text {mian }}^{82}$,

7. posługiwanie się pojęciami z darwinowskiej teorii doboru naturalnego (R.R. Nelson i S.G. Winter).

\section{Problemy badawcze w ramach teorii struktury branży}

Opisane powyżej podejścia badawcze w dużym stopniu determinują zakres zagadnień, którymi dana teoria się zajmuje. Tu znów, podobnie jak w poprzednim punkcie, konieczne staje się rozróźnienie zagadnień interesujących z punktu widzenia teorii branży i teorii firmy. Poniżej zostaną scharakteryzowane główne punkty zainteresowania poszczególnych nurtów w teorii branży.

80 Por. G.M. Hodgson, Economics and Evolution, Polity Press, Cambridge 1994.

81 Patrz P.A. David, Clio and the Economics of QWERTY, „American Economic Review” 1985. vol. 75(2) oraz D.C. North, Institutions, Institutional Change and Economic Performance, Cambridge University Press, Cambridge 1994.

82 Przeglądu zagadnień związanych z technologią dokonano w: Technical Change anả Economic Theory, red. G. Dosi, C. Freeman, R. Nelson, G. Silverberg, L. Soete, Pinter Publishers, London 1988. 


\section{Teoria neoklasyczna}

W ramach paradygmatu neoklasycznego można wyróżnić dwa kierunki zainteresowań branżą ${ }^{83}$ :

- Teoria równowagi ogólnej, której przedmiotem jest wyjaśnianie interakcji pomiędzy zachowaniami poszczególnych podmiotów rynkowych, sektorów i branż oraz ich wplywu na funkcjonowanie gospodarki jako całości. Stan gospodarki jest sumą stanów na rynkach cząstkowych ${ }^{84}$. Teoria ta nosi po części charakter normatywny, gdyż analizy poprzedzone są stawianiem celów na poziomie państwa.

- Teoria cen, inaczej nazywana teorią strategicznego zachowania. Przedmiotem zainteresowania są zachowania konkurencyjne przedsiębiorstw. Badane są takie czynniki, jak wielkość produkcji, zyskowność, ceny, strategie konkurencyjne itp. W ramach tego kierunku wykształciły się dwa nurty badań:

- Kierunek badań teoretycznych. W jego ramach rozwija się teorie dynamiki branży, asymetrycznej informacji, niekooperacyjne teorie gier oraz matematyczne modelowanie zachowań rynkowych.

- Nurt empiryczny (J.S. Bain, E. Mason) noszący również miano „harvardzkiej tradycji". Głównym obiektem zainteresowania jest paradygmat struktura-zachowanie-efektywność J.S. Baina ${ }^{85}$, w myśl którego struktura rynku wplywa na zachowania firm, a zachowania firm z kolei determinują efektywność rynku ${ }^{86}$.

Teoria branży w ujęciu neoklasycznym posiada ściśle określony zakres i przed. miot. Głównymi parametrami modeli są ilości i ceny dóbr, a w sferze badania zachowań te zjawiska, które bezpośrednio wpływają na pozycję materialną uczestnika rynku. Pomija się aspekty behawioralne i instytucjonalne, stosunki wewnątrz firmy oraz powiązania w sferze politycznej, społecznej oraz kulturowej $^{87}$.

\section{Szkola austriacka}

Przedmiotem badań szkoły austriackiej są wszelkie dynamiczne procesy zachodzące w branży. Dużo miejsca poświęca się analizowaniu procesów konkurencyjnych, procesów zmian w strukturze branży (badania zmian w stopniu koncentracji, powstawania barier wejścia i wyjścia) oraz cykliczności zjawisk gospodarczych. Rynek postrzegany jest jako system podlegający samoregulacji i nie wymagający ingerencji państwowej. Modele branży mają charakter dynamiczny. Jedną z charakterystycznych cech ekonomii austriackiej jest mate-

83 Zob. J.S. Bain, op. cit., s. 23-26.

84 Jednak hipoteza, iž rachunek marginalny umoźliwia zbadanie zależności pomiędzy zjawiskami na poziomie indywidualnych firm a zjawiskami na poziomie branży jest bardzo kontrowersyjna, por. P.J. Devine, R.M. Jones, W.J. Tyson, An Introduction to Industrial Economics, George Allen \& Unwin, London 1974, s. 28-29].

85 Por. J.S. Bain, op, cit.

86 Ostatnie badania empiryczne podważają słuszność tej tezy (por. M. Waterson, op. cit., s. 4).

87 J.S. Bain, op. cit., 5. 22. 
matyczne ujmowanie zjawisk gospodarczych, pomijanie aspektu równowagi w branży oraz podkreślanie roli czynnika cenowego.

\section{Nowa ekonomia instytucjonalna}

Wśród głównych kierunków analiz nowej ekonomii instytucjonalnej moźna wyróżnić następujące grupy ${ }^{88}$ zagadnień:

- prawa własności, agencja, koszty transakcyjne i monopol (opisane powyźej),

- ekonomia polityczna oraz zagadnienie wyborów społecznych,

- historia gospodarcza w kontekście instytucjonalno-społecznym,

- ideologia, procesy poznawania oraz rola ścieźki rozwojowej (path dependence). W zakresie teorii struktury branży nowa ekonomia instytucjonalna podejmuje próby wzbogacenia neoklasycznego paradygmatu o następujące zagadnienia:

1. podkreślenie roli otoczenia instytucjonalno-społecznego;

2. zwrócenie uwagi, iż rozwiązania rynkowe nie zawsze są optymalne (niepowodzenia rynku, koncepcja ścieżki rozwojowej);

3. przyjęcie założeń behawioralnych o ograniczonej racjonalności jednostek i dążeniu do innych celów niż maksymalizacja zysku oraz tym samym odejście od wizji homo oeconomicus;

4. zejście w analizach do poziomu jednostki (zerwanie z zasadą czarnej skrzynki);

5. analizy zachowań monopolistycznych i oligopolistycznych;

6. analizy ewolucji struktur rynkowych, reguł i konwencji;

7. dopuszczenie teorii normatywnych w zakresie polityki państwowej:

8. podnoszenie kwestii transformacji ustrojowej ${ }^{89}$.

\section{Nurt ekonomii ewolucyjnej}

$\mathrm{Na}$ gruncie teorii branży przedmiotem analizy ewolucyjnej są następujące zagadnienia $^{90}$ :

- badanie związków pomiędzy strukturą rynku, rozmiarem przedsiębiorstw i intensywnością procesów innowacyjnych. Nawiązuje się tu do hipotezy J.A. Schumpetera ${ }^{91}$, że struktura rynkowa jest główną determinantą zacho-

ss The Frontiers of the New Institutional Economics, red. J.N. Drobak, J.V.C. Nye, Academic Press, San Diego 1997, 5. Xvi.

89 D.C. North, The Contribution of the New Institutional Economics to an Understanding of the Transition Problem, United Nations University World Institute for Development Economics Research (UNU/WIDER), Helsinki 1997.

90 Por. R. Coombs, .Technological Opportunities and Industrial Organisation". w: Technical Change and Economic Theory, red. G. Dosi et al., op. cit.

91 Mówiąc o innowacjach w teorii J.A. Schumpetera należy wyróżnic dwa podejścia: w pierw. szym, u tzw. wczesnego Schumpetera [The Theory of Economic Development, 1912] innowacje i dzialalnosé przedsiębiorcza traktowana jest w dużej mierze jako proces nieprzewidywalny, cos. co powstaje w gospodarce samoczynnie lub na skutek przypadku; w późniejszych pracach [Capitalism, Socialism and Dentocracy, 1942], po analizach wielkich korporacji, J.A. Schumpeter sklania się ku poglądowi, że dzialalność innowacyjna prowadzona jest w ramach zaplanowanych prac badawczo-rozwojowych. 
wania innowacyjnego; analizy najczęściej dotyczą dodatniej korelacji intensywności prac badawczych ze stopniem koncentracji branży oraz wpływu działalności badawczej na wielkość firm ${ }^{92}$,

- koncepcje cyklu życia branży; w miarę dojrzewania branży charakter zmian technologicznych przesuwa się z innowacji na ulepszenia istniejącego produktu,

- modele stochastycznego wzrostu przedstawiające seryjne korelacje w tempach wzrostu firm ${ }^{93}$; modele te, po przyjęciu warunków początkowych, poddawane są komputerowej symulacji,

- badania wejść i wyjšć z branży w poszczególnych fazach cyklu życia branży oraz wplywu zmian technicznych na progi efektywności,

- badania związków pomiędzy możliwościami technologicznymi a innowacjami zachodzącymi w sferze produktu; w ramach tego nurtu bada się jak struktura rynkowa wplywa na wykorzystanie istniejących i nowych technologii. Podsumowując, paradygmat ewolucyjny w teorii branży ma na celu identyfikację następujących obiektów i zjawisk ${ }^{94}$.

- źródeł innowacji,

- cech charakterystycznych branży,

- natury procesów innowacyjnych w poszczególnych branżach,

- mechanizmów wzajemnych oddziaływań pomiędzy przedsiębiorstwami.

- ewolucji branź.

92 W badaniach empirycznych (R. Angelmar, Market Structure and Research Intensity in High-Technological-Opportunity Industries, „Journal of Industrial Economics", vol. 34(1), 1985) hipotezy te zostaly obalone poprzez wykazanie wplywu czynników nie wynikających bezpośrednio ze struktury branży i kształtujących się różnie dla różnych branż.

93 Np. R.R. Nelson i S.G. Winter (1982) dzielą firmy na imitatorów i innowatorów. Wzrost firmy powoduje wzrost nakładów na badania i rozwój, a to z kolei decyduje o tym, czy imitator jest w stanie przeksztalcić się w innowatora.

94 Por. G. Dosi, F. Malerba, L. Orsenigo, „Evolutionary Regimes and Industrial Dynamics”, w: Evolutionary and Neo-Schumpeterian Approaches to Economics, red. L. Magnusson, Kluwer Academic Publishers, Boston London 1994. 